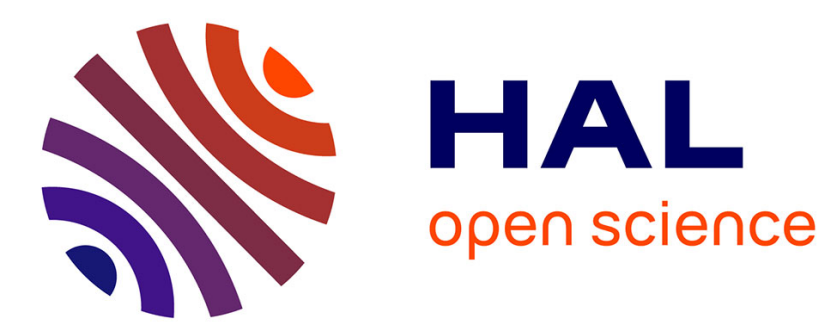

\title{
Application of the RICEWQ-VADOFT model to simulate leaching of propanil in rice paddies in Greece
}

Dimitrios G. Karpouzas, Ettore Capri, Euphemia Papadopoulou-Mourkidou

\section{To cite this version:}

Dimitrios G. Karpouzas, Ettore Capri, Euphemia Papadopoulou-Mourkidou. Application of the RICEWQ-VADOFT model to simulate leaching of propanil in rice paddies in Greece. Agronomy for Sustainable Development, 2005, 25 (1), pp.35-44. hal-00886274

\section{HAL Id: hal-00886274 \\ https://hal.science/hal-00886274}

Submitted on 1 Jan 2005

HAL is a multi-disciplinary open access archive for the deposit and dissemination of scientific research documents, whether they are published or not. The documents may come from teaching and research institutions in France or abroad, or from public or private research centers.
L'archive ouverte pluridisciplinaire HAL, est destinée au dépôt et à la diffusion de documents scientifiques de niveau recherche, publiés ou non, émanant des établissements d'enseignement et de recherche français ou étrangers, des laboratoires publics ou privés. 


\title{
Application of the RICEWQ-VADOFT model to simulate leaching of propanil in rice paddies in Greece
}

\author{
Dimitrios G. KARPOUZAS ${ }^{\mathrm{a} *}$, Ettore CAPRI ${ }^{\mathrm{a}}$, Euphemia PAPADOPOULOU-MOURKIDOU ${ }^{\mathrm{b}}$ \\ a Istituto di Chimica Agraria ed Ambientale, Universita Cattolica del Sacro Cuore, 29100 Piacenza, Italy \\ b Aristotle University of Thessaloniki, Laboratory of Pesticide Science, School of Agriculture, Thessaloniki 54124, Greece
}

(Received 29 June 2004; accepted 11 August 2004)

\begin{abstract}
In recent years models have become an integral part of the pesticide registration processes. However, there are still no validated models which can adequately describe the specific conditions of rice paddies. Accordingly, this study aimed to evaluate the capability of a proposed model, the RICEWQ-VADOFT model, to simulate leaching of propanil. Model performance was evaluated with a data set derived from a field study (1993-1994) carried out in five paddy fields in the southern part of the Axios river basin. Predicted and measured concentrations of propanil leaching to the deeper soil layer were in good agreement. The Root Mean Square Error (RMSE) and Modeling Efficiency (EF) values calculated for three of the five studied fields varied between 39.4-46.1 and 0.813-0.867, respectively, indicating good model performance. However, little agreement between predicted and observed pesticide concentrations was evident in the remaining two paddies. This was attributed to the presence of preferencial flow mechanisms in these particular fields, which facilitated the rapid transport of high concentrations of propanil into the deeper soil layers, and which the model was not able to predict.
\end{abstract}

RICEWQ-VADOFT / PECs / herbicides / leaching / rice paddies

\section{INTRODUCTION}

Contamination of surface (SW) and ground water (GW) systems by pesticides has been well documented by several monitoring studies across Europe. The potential for contamination of water bodies is high in areas where rice is cultivated under submerged conditions. The large amounts of water used during rice cultivation increases the likelihood of pesticide transport via runoff/drainage to adjacent surface waters and via leaching to groundwaters [3]. Several studies conducted in rice-cultivated areas in Europe have reported pesticide concentrations in excess of $0.1 \mathrm{\mu g} \mathrm{l}^{-1}$ in surface water and groundwater $[5,20]$. In Greece, a monitoring study employed in the main rice-cultivated area of Greece, the Axios River basin, revealed that two of the most common rice-herbicides, molinate and propanil, were frequently detected in the soil water collected from deep soil horizons $(160 \mathrm{~cm})$ at concentrations exceeding $0.1 \mu \mathrm{g}^{-1}$. Similar results have been reported for these herbicides in Italy [5] and Spain, where rice paddies were neighboring wetlands of great ecological importance [15]. The frequent detection of herbicides in surface water and groundwater systems neighboring rice-cultivated basins has raised concerns in Europe about their potential impact on both the environment and human health.

As field monitoring programs are money- and time-consuming, validated mathematical models have been integrated into the regulatory process for estimating Predicted Environmental Concentrations (PECs) of pesticides in surface waters and groundwaters. In recent years there have been significant advances in the use of mathematical models to predict pesticide environmental fate. Separate FOCUS (FOrum for the Co-ordination of pesticide environmental fate models and their USe) groups established within Europe have produced guideline documents for proper model use and recommended specific surface water and groundwater models to be used in standard agricultural scenarios for the inclusion of pesticides in Annex I $[12,13]$. However, according to Council Directive 91/414/EEC "particular conditions apply to rice cultivation and therefore certain specific criteria are inappropriate for evaluation purposes". In order to address this problem, a European Union (EU) working group, named MEDiterranean-RICE (MED-RICE), was formed and produced general guidelines and a first tier assessment model [14]. However, there is still a need for higher tier validated models, which can simulate pesticide environmental fate in rice paddies. The MED-RICE group has proposed that for higher tier risk assessment the RICE Water Quality model (RICEWQ) is the most relevant model for pesticide exposure assessment in adjacent surface waters. However, none of the models available for predicting groundwater PECs is capable of simulating the flooding conditions of a paddy field.

\footnotetext{
* Corresponding author: dimitrios.karpouzas@ unicatt.it
} 
RICEWQ was validated using specific scenarios in northern Italy and simulated well pesticide fate in paddy water and sediment and also losses of pesticide via overflow/runoff, but failed to predict leaching of pesticide in the vadose zone [6]. In order to adequately describe both leaching and runoff processes an improved version of the model, RICEWQ 1.6.2v, was developed, where an interface between the RICEWQ and VADOFT (VADOse zone Flow and Transport) models was built. VADOFT is a vadose zone transport model contained within the Pesticide Root Zone Model (PRZM) [7]. Preliminary evaluations of the RICEWQ $1.6 .2 \mathrm{v}$ in northern Italy showed that it could be an effective tool for exposure assessments under the particular conditions of rice cultivation [19]. However, further evidence on the efficiency of the model is required in order to allow for the model to be fully implemented for registration purposes within the EU. Consequently, our study intended to validate the RICEWQ-VADOFT model for predicting the environmental concentrations of propanil in GW aquifers under field-specific environmental and agricultural conditions in Greece.

\section{MATERIALS AND METHODS}

\subsection{Description of the model}

Assessments were made to evaluate leaching of pesticides in related $\mathrm{GW}$ aquifers using an integrated model that linked a fate and a transport model, RICEWQ and VADOFT, respectively. RICEWQ simulates water and chemical mass balance associated with the unique flooding conditions, overflow and controlled releases of water that are typical of rice paddies. The model applies the principle of mass balance to simulate water volume changes in the paddy and pesticide residues within the paddy from the point of chemical application:

$$
V \frac{\partial C}{\partial t}=\sum M_{\text {influx }}-\sum M_{\text {react }}-\sum M_{\text {outflux }}
$$

where $\partial C\left(\mathrm{mg} \mathrm{m}^{-3}\right)$ is the change in concentration over time $\partial t(\mathrm{~s}) ; \sum M_{\text {influx }}\left(\mathrm{mg} \mathrm{s}^{-1}\right)$ and $\sum M_{\text {outflux }}\left(\mathrm{mg} \mathrm{s}^{-1}\right)$ are cumulative influx and outflux of chemical mass from the control volume, $V\left(\mathrm{~m}^{3}\right)$ (i.e., the rice paddy), and $\sum M_{\text {react }}\left(\mathrm{mg} \mathrm{s}^{-1}\right)$ is mass transformation from all processes.

RICEWQ, using daily time steps, simultaneously tracks mass balance of chemicals in three environmental compartments: the rice foliage, water column and sediment. Chemical residues on foliage are expressed by the mass balance equation:

$$
\partial M_{F}=+M_{F a p p}-M_{F d e g}-M_{w a s h}-M_{h a r v}
$$

where $\partial M_{F}(\mathrm{mg})$ is the change in chemical mass on foliage; $M_{\text {Fapp }}(\mathrm{mg})$ is the mass of the pesticide applied which was intercepted by the foliage; $M_{F d e g}(\mathrm{mg})$ is the mass of the pesticide degraded in foliage following first order decay; $M_{F w a s h}(\mathrm{mg})$ is the mass washed off from foliage; $M_{\text {harv }}(\mathrm{mg})$ is the allocation of pesticide mass which has remained in the foliage at harvest.

The mass balance equation for the water column used by the model is:

$$
\begin{aligned}
\partial M_{w}= & M_{\text {wapp }}+M_{\text {wash }}-M_{\text {wdeg }}-M_{\text {volat }}-M_{\text {out }}-M_{\text {seep }} \\
& -M_{\text {bed }}-M_{\text {setl }}+M_{\text {resus }} \pm M_{\text {difus }}
\end{aligned}
$$

where $\partial M_{w}(\mathrm{mg})$ is the change in chemical mass in the paddy water. $M_{\text {wapp }}(\mathrm{mg})$ is the portion of the parent chemical not lost to drift or intercepted by the crop. $M_{w d e g}(\mathrm{mg})$ is the pesticide mass degraded in water following first order decay; $M_{\text {volat }}(\mathrm{mg})$ is the pesticide mass lost through volatilization across the airwater interface; $M_{\text {out }}(\mathrm{mg})$ is the pesticide mass lost by overflow or controlled drainage; $M_{\text {seep }}(\mathrm{mg})$ is the pesticide mass lost by seepage to the soil horizon beneath the paddy. $M_{\text {bed }}(\mathrm{mg})$ is the pesticide mass transferred to bed sediment by direct partitioning. $M_{\text {setl }}(\mathrm{mg})$ is the pesticide mass partitioning to paddy sediment by settlement of suspended sediment. $M_{\text {difus }}(\mathrm{mg})$ is the pesticide mass diffused between water and sediment.

The mass balance equation for paddy sediment which is used by the model is given below:

$$
\partial M s=-M_{\text {sdeg }}+M_{\text {bed }}+M_{\text {setl }}-M_{\text {resus }} \pm M_{\text {difus }}
$$

where $\partial M s(\mathrm{mg})$ is the change in chemical mass in paddy sediment; $M_{\text {sdeg }}(\mathrm{mg})$ is the pesticide mass degraded in sediment following first order decay and $M_{\text {resus }}(\mathrm{mg})$ is the pesticide mass lost by bed sediment and partitioned to paddy water by resuspension of the sediment.

VADOFT performs one-phase, one-dimensional transient or steady-state simulations of downward water flow and chemical solute transport in variably saturated porous media. The code employs the Galerkin finite-element technique to approximate the governing equations for water flow and chemical transport with spatial discretization (expressed as nodal points) performed using linear elements. VADOFT solves the Richards' equation, the governing equation for infiltration of water in the vadose zone:

$$
\frac{\partial}{\partial z} K k_{r w}\left(\frac{\partial \Psi}{\partial z}\right)=\eta \frac{\partial \Psi}{\partial t}
$$

where $\Psi$ is the pressure head $(\mathrm{m}), K$ is the saturated hydraulic conductivity $\left(\mathrm{m} \mathrm{s}^{-1}\right), k_{r w}$ is the relative permeability (dimensionless), $z$ is the vertical coordinate $(\mathrm{m}), t$ is time (s), and $\eta$ is the effective water storage capacity $\left(\mathrm{m}^{-1}\right)$.

The governing equation for one-dimensional transport of a non-conservative chemical solute species in a variably saturated soil takes the form:

$$
\frac{\partial}{\partial z}\left(D \frac{\partial c}{\partial z}\right)-q \frac{\partial c}{\partial z}=\theta R\left(\frac{\partial c}{\partial t}\right)+\lambda c
$$

where $D$ is the apparent dispersion coefficient $\left(\mathrm{m}^{2} \mathrm{~s}^{-1}\right), c$ is the solute concentration $\left(\mu \mathrm{g}^{-1}\right), \theta$ is the volumetric water content $\left(\mathrm{cm}^{3} \mathrm{~cm}^{-3}\right), q$ is the vertical Darcy velocity $\left(\mathrm{m} \mathrm{s}^{-1}\right), R$ is the retardation coefficient (dimensionless), and $\lambda$ is the first-order decay constant $\left(\mathrm{s}^{-1}\right)$.

Both models use a water-balance model for calculating water balance in the paddy and the vadose zone:

$$
\frac{\partial S}{\partial t}=\sum I-\sum O
$$

where the change in storage $(\partial S)\left(\mathrm{m}^{3}\right)$ over time $(\partial t)(\mathrm{s})$ is equal to the cumulative sum of inflow $\left(\sum I\right)\left(\mathrm{m}^{3} \mathrm{~s}^{-1}\right)$ minus the cumulative sum of outflow $\left(\sum O\right)\left(\mathrm{m}^{3} \mathrm{~s}^{-1}\right)$. 
Table I. Cropping history and application rates of propanil $\left(\mathrm{kg} \mathrm{ha}^{-1}\right)$ in the studied paddy fields.

\begin{tabular}{lcclll}
\hline Studied & \multicolumn{3}{c}{ Cropping history } & \multicolumn{2}{c}{ Application rate } \\
\cline { 2 - 6 } paddies & 1992 & 1993 & 1994 & 1993 & 1994 \\
\hline Vrahia 1 & cotton & rice & rice & 8.75 & 3.50 \\
Vrahia 2 & corn & rice & rice & 5.25 & 8.75 \\
Vrahia 3 & alfalfa & rice & rice & 5.25 & 8.75 \\
Vrahia 4 & rice & rice & rice & 5.25 & 5.25 \\
Halastra & rice & rice & rice & 5.25 & 5.25 \\
\hline
\end{tabular}

The models were integrated by transferring water and pesticide flux predicted as seepage by RICEWQ as prescribed boundary loadings into VADOFT. The top $0.1-5 \mathrm{~cm}$ of the soil profile is represented by the active sediment layer in RICEWQ and the remainder of the soil profile is represented as multiple compartments in VADOFT. The bottom of the active sediment layer is the interface between the two sub-systems represented by the two models.

RICEWQ is driven by daily weather data and operates at a sub-daily time step to obtain the daily decay, runoff and leaching amount by integration. When irrigation and precipitation exceed the depth of the paddy outlet, overflow occurs. When soil moisture in the paddy exceeds field capacity, seepage to VADOFT commences. As the paddy dries, soil moisture can decrease to the wilting point through evapotranspiration. Water and chemical flux across the interface is one-dimensional. It should be clarified that the term seepage refers to water and chemicals percolating from paddy sediment into the vadose zone and leaching refers to the downward movement of water and chemicals within the vadose zone or from the vadose zone to GW. For a full description of both models the reader is referred to the related user manuals [7, 24].

\subsection{Site details and measurements}

The field study was conducted during 1993-1994 in different rice paddies, located in the southern part of the Axios River basin. The southern part of the basin is considered the main ricecultivating area of Greece, constituting over $70 \%$ of the whole rice-cultivated area in Greece. Two areas in the southwest (area of Vrahia) and southeast (area of Halastra) regions of the basin were selected for carrying out the monitoring study. The area of Vrahia consisted of four bordering paddy fields, unlike the area of Halastra where only one field was cultivated with rice during 1993-1994. Information concerning the cropping history and pesticide application rates is listed in Table I.

The compound studied was the herbicide propanil $(3,4$ dichloropropionanilide) which was routinely used in the studied paddies for the control of barnyardgrass (Echinochloa crusgalli L. Beauv). All paddies were partially drained a day before the application of propanil, which was applied 30-45 days after seeding. The rice paddies were re-flooded $24-48 \mathrm{~h}$ after pesticide application, but water circulation was halted for 5-10 days, varying between paddies. When water circulation was re-established, the water level in the paddies was maintained at between 9 and $11 \mathrm{~cm}$.
Suction lysimeters were used for the collection of soil water samples, which were analyzed for pesticide residues. A 75-mm hole was drilled to the required depth by a hand auger and the suction lysimeter was then placed in the hole to the required depth. A slurry of silica sand was poured into the hole to ensure that the ceramic cup, when the slurry has dried out, will be totally surrounded by silica sand. The silica sand is used to ensure as intimate a connection as possible between the ceramic cup and the soil so that the suction is transmitted effectively to the soil moisture. When the slurry was firm, the spoil from augering was replaced in the same sequence as it was removed, with great care being taken to avoid bridging the annulus. This installation procedure was followed in order to minimize the possibility of establishing artificial preferential flowpaths at the sides of the lysimeters [9]. One suction lysimeter was vertically installed at the margin of each rice paddy field with the active portion of the ceramic cap at a depth of $160 \mathrm{~cm}$. Rice is cultivated under submerged conditions and the installation of lysimeters at the center of the rice paddy fields was not feasible, since the lysimeters would have been inaccessible for sampling during the rice-cropping season. All lysimeters remained in the fields during the entire experimental period. Intact soil cores were removed $(0-160 \mathrm{~cm})$ with a soil auger from each field and the physicochemical properties of each soil were measured (Tabs. II and III). A more detailed description of the monitoring study is presented by Papadopoulou-Mourkidou et al. [20].

\subsection{Model parameterization and assumptions}

The input variables/parameters required by the RICEWQVADOFT model are shown in Tables IV and V. Crop practices (e.g surface area of paddies, crop emergence and harvest date, pesticide application date and rate, and maximum area of crop coverage) and water management parameters (paddy water depth of initial and terminal irrigation and respective dates, depth of paddy outlet, and irrigation and drainage rate) were obtained from field observations. The period of simulation represented the whole rice-cultivating season in northern Greece, from 1 May up to 12 October. During the current field experiment, the rice was seeded in all studied paddies between 1 and 5 of May in both years. The rice crop emerged 5-7 days after seeding depending on the temperature of the irrigation water. Maturation and drainage of the studied paddies occurred between 1-20 of September and harvesting of the rice had been completed in all studied fields by the 12 th of October. The exact dates and intended doses of propanil used in each field varied (Tab. I). 
Table II. Physicochemical properties of the soil horizon beneath the studied paddies of the Vrahia area.

\begin{tabular}{|c|c|c|c|c|c|c|c|c|c|c|c|}
\hline Fields & $\begin{array}{l}\text { Surface } \\
\text { area (ha) }\end{array}$ & $\begin{array}{l}\text { Soil horizon } \\
\quad(\mathrm{cm})\end{array}$ & $\begin{array}{c}\text { Organic } \\
\text { matter }(\%)\end{array}$ & $\mathrm{pH}$ & $\begin{array}{l}\text { Sand } \\
(\%)\end{array}$ & $\begin{array}{l}\text { Clay } \\
(\%)\end{array}$ & $\begin{array}{c}\text { Loam } \\
(\%)\end{array}$ & $\begin{array}{l}\text { Bulk density } \\
\quad\left(\mathrm{t} \mathrm{m}^{-3}\right)\end{array}$ & $\begin{array}{l}\text { Wilting point } \\
\left(\mathrm{cm}^{3} \mathrm{~cm}^{-3}\right)\end{array}$ & $\begin{array}{l}\text { Field capacity } \\
\left(\mathrm{cm}^{3} \mathrm{~cm}^{-3}\right)\end{array}$ & $\begin{array}{l}\text { Soil } \\
\text { texture }\end{array}$ \\
\hline \multirow[t]{6}{*}{ Vrahia 1} & 3 & $0-20$ & 2.37 & 8.8 & 42.8 & 49.2 & 8 & 1.42 & 0.64 & 0.83 & $\mathrm{C}^{\mathrm{a}}$ \\
\hline & & $20-40$ & 1.31 & 9.0 & 44.8 & 51.2 & 4 & 1.41 & 0.69 & 0.85 & $\mathrm{C}$ \\
\hline & & $40-60$ & 1.71 & 9.1 & 44.8 & 53.2 & 2 & 1.41 & 0.69 & 0.85 & $\mathrm{C}$ \\
\hline & & $60-80$ & 1.25 & 9.7 & 44.8 & 55.2 & 0 & 1.44 & 0.72 & 0.88 & $\mathrm{C}$ \\
\hline & & $80-120$ & 0.93 & 10.1 & 44.8 & 49.2 & 6 & 1.47 & 0.68 & 0.87 & $\mathrm{C}$ \\
\hline & & $120-160$ & 2.92 & 10.2 & 26.8 & 53.2 & 20 & 1.34 & 0.63 & 0.85 & $\mathrm{CL}$ \\
\hline \multirow[t]{6}{*}{ Vrahia 2} & 4.5 & $0-20$ & 2.84 & 8.8 & 36.4 & 47.6 & 16 & 1.39 & 0.61 & 0.83 & $\mathrm{CL}^{\mathrm{a}}$ \\
\hline & & $20-40$ & 3.19 & 9.1 & 36.4 & 47.6 & 16 & 1.30 & 0.54 & 0.77 & $\mathrm{CL}$ \\
\hline & & $40-60$ & 2.53 & 9.7 & 36.4 & 47.6 & 16 & 1.39 & 0.61 & 0.83 & $\mathrm{CL}$ \\
\hline & & $60-80$ & 1.63 & 10.0 & 36.4 & 53.6 & 10 & 1.40 & 0.68 & 0.86 & $\mathrm{CL}$ \\
\hline & & $80-100$ & 1.81 & 9.8 & 42.4 & 51.6 & 6 & 1.38 & 0.66 & 0.85 & $\mathrm{C}$ \\
\hline & & $100-160$ & 0.09 & 9.9 & 42.4 & 53.6 & 4 & 1.48 & 0.76 & 0.93 & $\mathrm{C}$ \\
\hline \multirow[t]{5}{*}{ Vrahia 3} & 3.5 & $0-20$ & 3.00 & 9.8 & 36.8 & 53.2 & 10 & 1.38 & 0.66 & 0.85 & $\mathrm{C}$ \\
\hline & & $20-40$ & 2.17 & 8.7 & 36.8 & 53.2 & 10 & 1.36 & 0.65 & 0.84 & $\mathrm{C}$ \\
\hline & & $40-60$ & 2.51 & 8.8 & 36.8 & 47.2 & 16 & 1.39 & 0.61 & 0.83 & $\mathrm{C}$ \\
\hline & & $60-80$ & 2.60 & 9.2 & 36.8 & 47.2 & 16 & 1.39 & 0.61 & 0.83 & $\mathrm{C}$ \\
\hline & & $80-160$ & 2.42 & 10.0 & 36.8 & 53.2 & 10 & 1.36 & 0.65 & 0.84 & $\mathrm{C}$ \\
\hline \multirow[t]{4}{*}{ Vrahia 4} & 2.6 & $0-20$ & 3.73 & 8.7 & 36.8 & 47.2 & 16 & 1.31 & 0.55 & 0.77 & CL \\
\hline & & $20-40$ & 3.48 & 8.8 & 36.8 & 47.2 & 16 & 1.31 & 0.55 & 0.77 & $\mathrm{CL}$ \\
\hline & & $40-60$ & 3.55 & 9.8 & 36.8 & 45.2 & 18 & 1.30 & 0.54 & 0.77 & CL \\
\hline & & $60-160$ & 2.29 & 9.8 & 36.8 & 43.2 & 20 & 1.43 & 0.58 & 0.82 & CL \\
\hline
\end{tabular}


Table III. Physicochemical properties of the soil horizon beneath the studied paddy of the Halastra area.

\begin{tabular}{|c|c|c|c|c|c|c|c|c|c|c|}
\hline $\begin{array}{l}\text { Surface } \\
\text { area (ha) }\end{array}$ & $\begin{array}{l}\text { Soil horizon } \\
\quad(\mathrm{cm})\end{array}$ & $\begin{array}{c}\text { Organic } \\
\text { matter }(\%)\end{array}$ & $\mathrm{pH}$ & $\begin{array}{l}\text { Sand } \\
(\%)\end{array}$ & $\begin{array}{l}\text { Clay } \\
(\%)\end{array}$ & $\begin{array}{l}\text { Loam } \\
(\%)\end{array}$ & $\begin{array}{l}\text { Bulk density } \\
\quad\left(\mathrm{t} \mathrm{m}^{-3}\right)\end{array}$ & $\begin{array}{l}\text { Wilting point } \\
\left(\mathrm{cm}^{3} \mathrm{~cm}^{-3}\right)\end{array}$ & $\begin{array}{l}\text { Field capacity } \\
\quad\left(\mathrm{cm}^{3} \mathrm{~cm}^{-3}\right)\end{array}$ & $\begin{array}{c}\text { Soil } \\
\text { texture }\end{array}$ \\
\hline \multirow[t]{5}{*}{7.5} & $0-20$ & 4.39 & 9.2 & 24.0 & 76.0 & 0 & 1.01 & 0.55 & 0.72 & $\mathrm{C}$ \\
\hline & $20-40$ & 3.63 & 8.8 & 24.0 & 76.0 & 0 & 1.01 & 0.55 & 0.72 & $\mathrm{C}$ \\
\hline & $40-60$ & 4.57 & 9.5 & 24.0 & 76.0 & 0 & 1.01 & 0.55 & 0.72 & $\mathrm{C}$ \\
\hline & $60-80$ & 4.37 & 9.8 & 24.0 & 76.0 & 0 & 1.01 & 0.55 & 0.72 & $\mathrm{C}$ \\
\hline & $80-160$ & 3.86 & 10 & 24.0 & 76.0 & 0 & 1.01 & 0.55 & 0.72 & $\mathrm{C}$ \\
\hline
\end{tabular}

Table IV. Summary of the input parameters used in the RICEWQ model.

\begin{tabular}{|c|c|c|c|c|}
\hline Data & Parameters & Units & Comments & Values \\
\hline \multirow[t]{7}{*}{ Crop Practices } & Emergence date & & & May 7 \\
\hline & Harvest date & & & October 12 \\
\hline & Maximum crop coverage & & At maximum crop leaf area & 0.95 \\
\hline & Deposition of pesticide residues at harvest & & $\begin{array}{c}-1=\text { left alone; } \\
-2=\text { foliar residues removed }\end{array}$ & -1 \\
\hline & Number of pesticide applications per year & & & 1 \\
\hline & Closure of paddy after pesticide application & days & & $5-10$ \\
\hline & Application efficiency & & Estimated & 1.00 \\
\hline \multirow[t]{8}{*}{ Hydrology } & $\begin{array}{c}\text { Paddy water depth at initial and terminal } \\
\text { irrigation }\end{array}$ & $\mathrm{cm}$ & & $9.5 / 11.0$ \\
\hline & Depth of paddy outlet & $\mathrm{cm}$ & & 11.0 \\
\hline & Irrigation rate & $\mathrm{cm} \mathrm{d}^{-1}$ & Calculated & 3.50 \\
\hline & Drainage rate & $\mathrm{cm} \mathrm{d}^{-1}$ & Calculated & 0.432 \\
\hline & Seepage rate & $\mathrm{cm} \mathrm{d}^{-1}$ & Calibrated & 0.90 \\
\hline & $\begin{array}{l}\text { Depth of active } \\
\text { sediment layer }\end{array}$ & $\mathrm{cm}$ & Calibrated & 0.10 \\
\hline & Suspended sediment concentration & $\mathrm{mg}^{-1}$ & User estimated & 45.0 \\
\hline & Mixing depth to allow direct partitioning to bed & $\mathrm{cm}$ & User estimated & 0.10 \\
\hline \multirow[t]{3}{*}{ Pesticide } & Water/sediment partition coefficient (Koc) & $1 \mathrm{~kg}^{-1}$ & Literature [23] & 149 \\
\hline & Decay rate in water/sediment/plant & $d^{-1}$ & Literature $[22,23]$ & $\begin{array}{c}0.230 / 0.230 / \\
0.1385\end{array}$ \\
\hline & Pesticide water solubility & $\mathrm{mg}^{-1}$ & Literature [23] & 130 \\
\hline
\end{tabular}

Table V. A summary of the soil physical and hydraulic parameters used by VADOFT for the texturally different soil layers: clay and clay loam observed in the vadose zone of the studied rice paddies.

\begin{tabular}{lcc}
\hline Parameters & Clay & Clay loam \\
\hline Saturated hydraulic conductivity $\left(\mathrm{cm} \mathrm{d}^{-1}\right)$ & 4.80 & 6.24 \\
Saturated water content $\left(\theta_{\mathrm{S}}\right)\left(\mathrm{cm}^{3} \mathrm{~cm}^{-3}\right)$ & 0.38 & 0.41 \\
Residual water content $\left(\theta_{\mathrm{r}}\right)\left(\mathrm{cm}^{3} \mathrm{~cm}^{-3}\right)$ & 0.068 & 0.095 \\
Effective porosity (dimensionless) & 0.312 & 0.315 \\
Residual water phase saturation (dimensionless) & 0.232 & 0.179 \\
Leading coefficient of the saturation versus capillary head $(\alpha)\left(\mathrm{cm}^{-1}\right)$ & 0.008 & 0.019 \\
Power index of saturation versus capillary head relationship $(\beta)\left(\mathrm{cm}^{-1}\right)$ & 1.090 & 1.310 \\
Power index of the saturation versus capillary head relationship $(\gamma)\left(\mathrm{cm}^{-1}\right)$ & 0.080 & 0.240 \\
Longitudinal dispersion $(\mathrm{cm})$ & Soil layer-dependent & Soil layer-dependent \\
Retardation coefficient $($ dimensionless $)$ & Soil layer-dependent & Soil layer-dependent \\
Darcy velocity $\left(\mathrm{cm} \mathrm{d} \mathrm{d}^{-1}\right)$ & Soil layer-dependent & Soil layer-dependent \\
\hline
\end{tabular}


Pesticide decay rates in soil/sediment [23], water and foliage [22], and the pesticide water/sediment partition coefficient Koc were derived from the literature [23]. Subsequently, Kd values which are required as inputs for the model were calculated for each field. Propanil is not considered volatile and the volatilization subroutine of the model was switched off. Hydrological properties of the soil were derived from pedo-transfer functions. Field capacity $\left(\mathrm{cm}^{3} \mathrm{~cm}^{-3}\right)$, wilting point $\left(\mathrm{cm}^{3} \mathrm{~cm}^{-3}\right)$ and bulk density $\left(\mathrm{t} \mathrm{m}^{-3}\right)$ were derived from Baumer-ASW/EPIC using the SoilPar software according to measured soil physical and chemical data (Tabs. II, III) [2]. The initial soil moisture content $\left(\mathrm{cm}^{3} \mathrm{~cm}^{-3}\right)$ was set to field capacity.

A vadose zone of $160 \mathrm{~cm}$ was simulated in all studied fields and it was divided into separate layers according to differences in soil properties in each individual field (Tabs. II, III). The size of the model layers [nodal space $z(\mathrm{~cm})$ ] was set according to the Peclet and Courant number criteria:

$$
\frac{\Delta z}{\alpha_{L}} \leq 4
$$

where $\alpha_{L}$ is the longitudinal dispersion $(\mathrm{cm})$. In the absence of site-specific $\alpha_{L}$ values it is recommended that the dispersivity be chosen as one-tenth of the distance of the flow path or $\alpha_{L}=$ $0.1 \chi_{v}$, where $\chi_{v}$ is the thickness of the vadose zone $(\mathrm{cm})$ [7].

In the simulation, transient water flow was assigned to modules within VADOFT relating to both water flow and chemical transport. A seepage rate of $0.90 \mathrm{~cm} \mathrm{~d}^{-1}$ was obtained by calibration to the experimental concentrations of propanil in the field Vrahia 4 in 1993. This value of seepage rate is within the range given in the literature $\left(0.02-1.56 \mathrm{~cm} \mathrm{~d}^{-1}\right)$ for similar rice fields $[14,25]$. A gradual reduction in the degradation rate of propanil with soil depth was assumed due to the reduced microbial activity at deeper soil layers. Therefore, the degradation rate of propanil in the paddy sediment $\left(0.230 \mathrm{~d}^{-1}\right)$ was multiplied by a degradation factor (DF) of 0.1 in the case of a uniform soil horizon (Vrahia 3, 4 and Halastra) or by DFs of 0.1 and 0.01 for the first and the second soil layer, respectively, in the case of a soil horizon consisting of two texturally different zones (Vrahia 1 and 2). Similar degradation rates in subsurface soil horizons have been reported before for other herbicides [1, 21]. It should be noted that the model allows changes in the rate of degradation with soil depth only in each different porous material. This constitutes a problem for adequately describing the decrease in the pesticide degradation rate with soil depth in a soil horizon $(0-160 \mathrm{~cm})$ with a uniform texture. The Darcy velocity $q\left(\mathrm{~cm} \mathrm{~d}^{-1}\right)$ and retardation coefficient $R$ (dimensionless) were calculated for each different porous material in the vadose zone using equations (10) and (11), respectively:

$$
\begin{aligned}
q & =K \times \frac{L+h}{L} \\
R & =1+\frac{K d \times \rho}{\theta s}
\end{aligned}
$$

where $K$ is the saturated hydraulic conductivity $\left(\mathrm{cm} \mathrm{d}^{-1}\right), L$ is the length of the vadose zone layer for which Darcy velocity is measured $(\mathrm{cm}), h$ is the hydraulic height $(\mathrm{cm}), K d\left(\mathrm{~cm}^{3} \mathrm{~g}^{-1}\right)$ is the partition coefficient, $\rho\left(\mathrm{g} \mathrm{cm}^{3}\right)$ is the bulk density and $\theta_{s}$ $\left(\mathrm{cm}^{3} \mathrm{~cm}^{-3}\right)$ is the saturated water content.

Input parameters for the VADOFT model including saturated hydraulic conductivity, saturated water content $\left(\theta_{s}\right)$, residual water content $\left(\theta_{r}\right)$ and van Genuchten model parameters $\alpha, \beta$ and $\gamma$ were derived using the PRZM 3.0 Users' Manual for the different porous materials of the soil horizon (Tab. V) [7]. Other parameters such as effective porosity and residual water phase saturation were calculated from $\theta_{s}$ and $\theta_{r}$ for each soil layer.

The model requires daily precipitation $(\mathrm{cm})$ and daily evaporation $(\mathrm{cm})$ data during the simulation period. In the model, evapotranspiration is assumed to be equal to pan evaporation, which is a valid assumption for an aquatic environment [17]. The potential evapotranspiration was calculated with the Penman-Monteith method using RadEst 3.00 [10].The model does not allow both irrigation and drainage to occur concurrently. The continuous flow in and out of rice paddies in Greece was sufficiently represented by a simulated water management, where commencement of irrigation was triggered when the water level in the paddy had fallen below $9.5 \mathrm{~cm}$, and irrigation was halted every time the water level exceeded $11 \mathrm{~cm}$.

Parameters such as the depth of active sediment (DACT) and the number of nodal points in the vadoze zone (NP) were derived after calibration. Calibration was done using a simple approach where each parameter was varied, one after the other, with all other parameters being kept at their nominal values. These parameters are not readily determined experimentally and their values were varied according to expert judgment. DACT was given 9 values $(5,4,3,2,1,0.7,0.5,0.3$ and 0.1 $\mathrm{cm})$ while NP was given 5 values $(5,11,21,31$ and 41). Nominal values for DACT and NP were $0.1 \mathrm{~cm}$ and 5 , respectively. The model was calibrated against measured data from the field Vrahia 4 in 1993 and assessment of the values derived from the calibration was performed against measured data from other fields in 1993 and 1994. Such a testing exercise has been reported as acceptable for assessing the validity of parameters derived from calibration [11]. Model performance was objectively assessed by visual comparison of the agreement between predicted and measured values. The Root Mean Square Error (RMSE) and the Modeling Efficiency (EF) calculated from the observed and the predicted data were also used to express the overall fit of the model simulation:

$$
\begin{gathered}
\mathrm{RMSE}=\frac{100}{\bar{O}} \sqrt{\frac{\sum_{i=1}^{n}(P i-O i)^{2}}{n}} \\
E F=\frac{\left(\sum(O i-\bar{O})^{2}-\sum(P i-O i)^{2}\right)}{\sum(O i-\bar{O})^{2}}
\end{gathered}
$$

where $P i$ and $O i$ are the predicted and observed values, respectively, $\bar{O}$ is the mean of the observed values and $n$ is the number of observations. A perfect fit of the model predictions with the measured values results in an RMSE value of zero and an EF value of 1 [18].

\section{RESULTS AND DISCUSSION}

\subsection{Input data analysis}

Specific input parameters which were not measurable and have been identified from previous studies as critical for the model's performance were calibrated [19]. The number of 

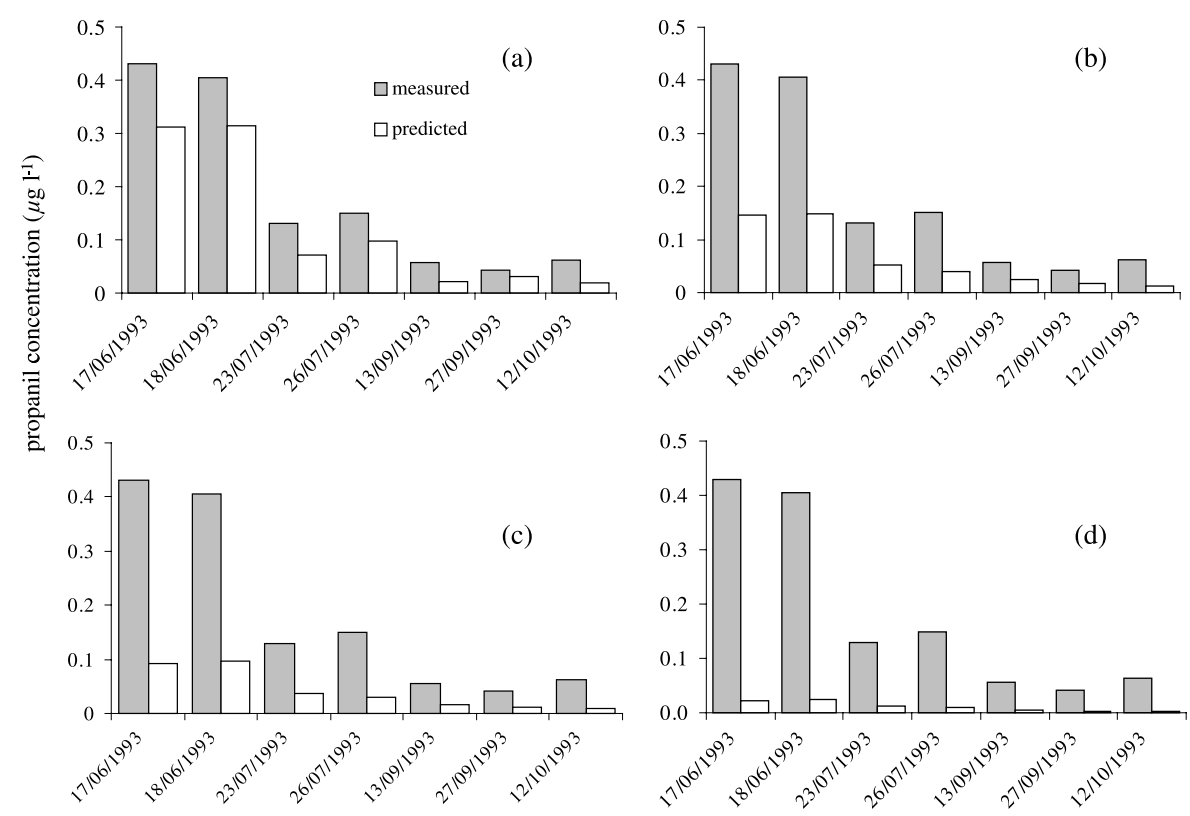

Figure 1. The predicted and measured concentrations of propanil in the soil water at $160 \mathrm{~cm}$ depth when the input variable DACT (depth of active sediment) was set to (a) 0.1 ; (b) 0.5 ; (c) 1 and (d) $5 \mathrm{~cm}$.

Table VI. The measured and predicted concentrations of propanil $\left(\mu \mathrm{g}^{-1}\right)$ leaching to the deeper soil layers $(160 \mathrm{~cm})$ when the number of nodal points was varied between 5 and 31 .

\begin{tabular}{cccccc}
\hline Sampling dates & Measured & \multicolumn{3}{c}{ Predicted - Nodal points number } \\
\cline { 3 - 5 } & & 5 & 11 & 21 & 0 \\
\hline $17 / 06 / 1993$ & 0.430 & 0.298 & $9.2 \times 10^{-5}$ & 0 & 0 \\
$18 / 06 / 1993$ & 0.405 & 0.288 & $5.3 \times 10^{-5}$ & 31 \\
$23 / 07 / 1993$ & 0.130 & 0.072 & $1.4 \times 10^{-5}$ & $3 \times 10^{-11}$ & 0 \\
$26 / 07 / 1993$ & 0.150 & 0.054 & $5.3 \times 10^{-5}$ & $1 \times 10^{-11}$ & 0 \\
$13 / 09 / 1993$ & 0.056 & 0.040 & $6.5 \times 10^{-5}$ & $3.4 \times 10^{-8}$ & $1.6 \times 10^{-9}$ \\
$27 / 09 / 1993$ & 0.042 & 0.036 & $7.5 \times 10^{-5}$ & $7.6 \times 10^{-8}$ & $1.2 \times 10^{-8}$ \\
$12 / 10 / 1993$ & 0.063 & 0.025 & $5.3 \times 10^{-5}$ & $5.4 \times 10^{-8}$ & $8.4 \times 10^{-9}$ \\
\hline
\end{tabular}

nodal points used for the compartmentalization of the soil horizon was calibrated and the value of 5 for propanil showed the best fit to the measured pesticide concentrations (Tab. VI). In contrast, when NP values of 11,21,31 and 41 (data not shown) were used, the model under-predicted the amounts of propanil leaching to the deeper soil layers $(160 \mathrm{~cm})$. Previous studies using the RICEWQ-VADOFT model suggested that a decrease in the number of nodal points increases the amounts of solute leaching to the deeper soil layers [19]. Therefore, in our study a low number of nodal points was selected to generate more leaching.

Another parameter to which RICEWQ-VADOFT was very sensitive was the depth of the active sediment layer (DACT). A range of values between 0.1 and $5 \mathrm{~cm}$ was tested in order to identify the value providing the best fit to the 1993 experimen- tal data of the field Vrahia 4 (Fig. 1). The best agreement between measured and predicted pesticide concentrations was obtained with a DACT value of $0.1 \mathrm{~cm}$ (Fig. 1). Such low values were necessary in order to encourage higher amounts of pesticide to enter the vadose zone. Lower values of DACT represent a thinner active sediment layer; a shorter time of interaction between the pesticide and sediment and, consequently, lower pesticide losses due to adsorption and degradation in the active sediment layer. The effect of the input variable DACT on the predicted total amount of propanil seeping into the vadose zone is shown in Figure 2. The predicted amounts of propanil seeping into the vadose zone are strongly influenced by the values of DACT. Increases in the values of DACT resulted in a subsequent decrease in the total amount of pesticide seeping into the vadose zone as predicted by the model. 


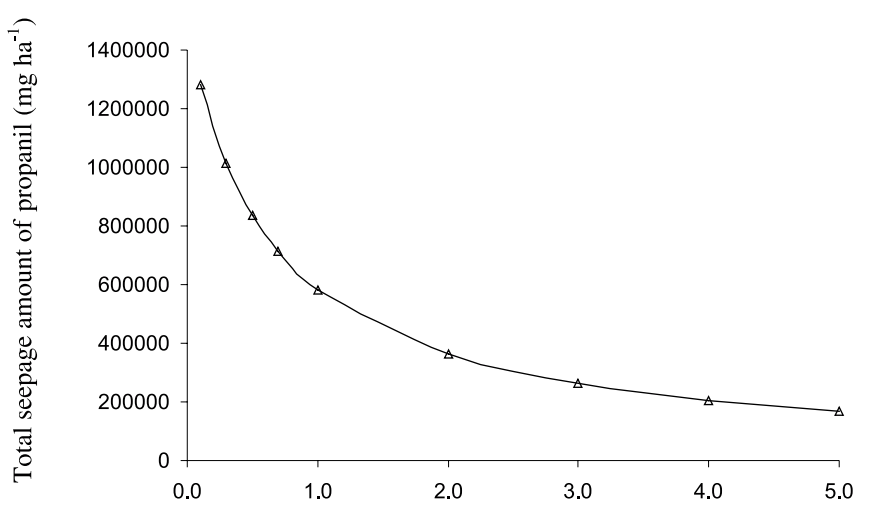

DACT values $(\mathrm{cm})$

Figure 2. The influence of the variable DACT (depth of active sediment) on the amount of pesticide seeping into the vadose zone as predicted by the model.

\subsection{Model predictions of propanil leaching to the vadose zone}

The model, in three of the five studied paddies, simulated leaching of propanil well (Figs. 3c, d and 4). RMSE and EF for the fields Vrahia 3, 4 and Halastra ranged between 39.4-46.1 and $0.813-0.867$, respectively, indicating good model performance (Tab. VII). Lower but acceptable agreement between predicted and measured concentrations of propanil was observed in the field Vrahia 2 (Fig. 3b) and this is mirrored in the RMSE and $\mathrm{EF}$ values of 83.6 and 0.646 , respectively (Tab. VII). The lower agreement between predictions and measurements in the
Table VII. The RMSE and EF values calculated by the predicted and measured concentrations of propanil in each of the studied paddies.

\begin{tabular}{lcc}
\hline Fields & RMSE & EF \\
\hline Vrahia 1 & 128.1 & 0.205 \\
Vrahia 2 & 83.6 & 0.646 \\
Vrahia 3 & 39.4 & 0.867 \\
Vrahia 4 & 43.7 & 0.819 \\
Halastra & 46.1 & 0.813 \\
\hline
\end{tabular}

field Vrahia 2 could be attributed to the high concentration of propanil $\left(2.1 \mu \mathrm{g}^{-1}\right)$ detected in the first sampling event in 1994 (7/6/94) which the model failed to predict. The lowest agreement between predicted and measured propanil concentrations was evident in the field Vrahia 1 (Fig. 3a) where RMSE and EF values of 128.1 and 0.205 were obtained, suggesting low agreement (Tab. VII). This could be attributed to the extreme concentration of propanil of $3.8 \mu \mathrm{g} \mathrm{l}^{-1}$ which was detected in a lysimeter sample in this field. Such a high concentration of propanil could be explained by the presence of bypass flow mechanisms in the specific soils. The soils of the area are predominantly clay/clay loams which are generally considered more vulnerable to bypass flow leaching $[4,8]$ The dominance of bypass flow mechanisms in the specific site is further supported by the observation that these extreme concentrations of propanil were measured in the first sampling event (17/6/1993) and occurred a few days after the application of propanil (Fig. 3a). Previous studies have shown that pesticides can quickly enter sub-surface soil in significant concentrations by infiltrating water through macropores in structured clay soils [4].

It has been suggested that improper installation of suction lysimeters in clay soils might create new bypass flow-paths
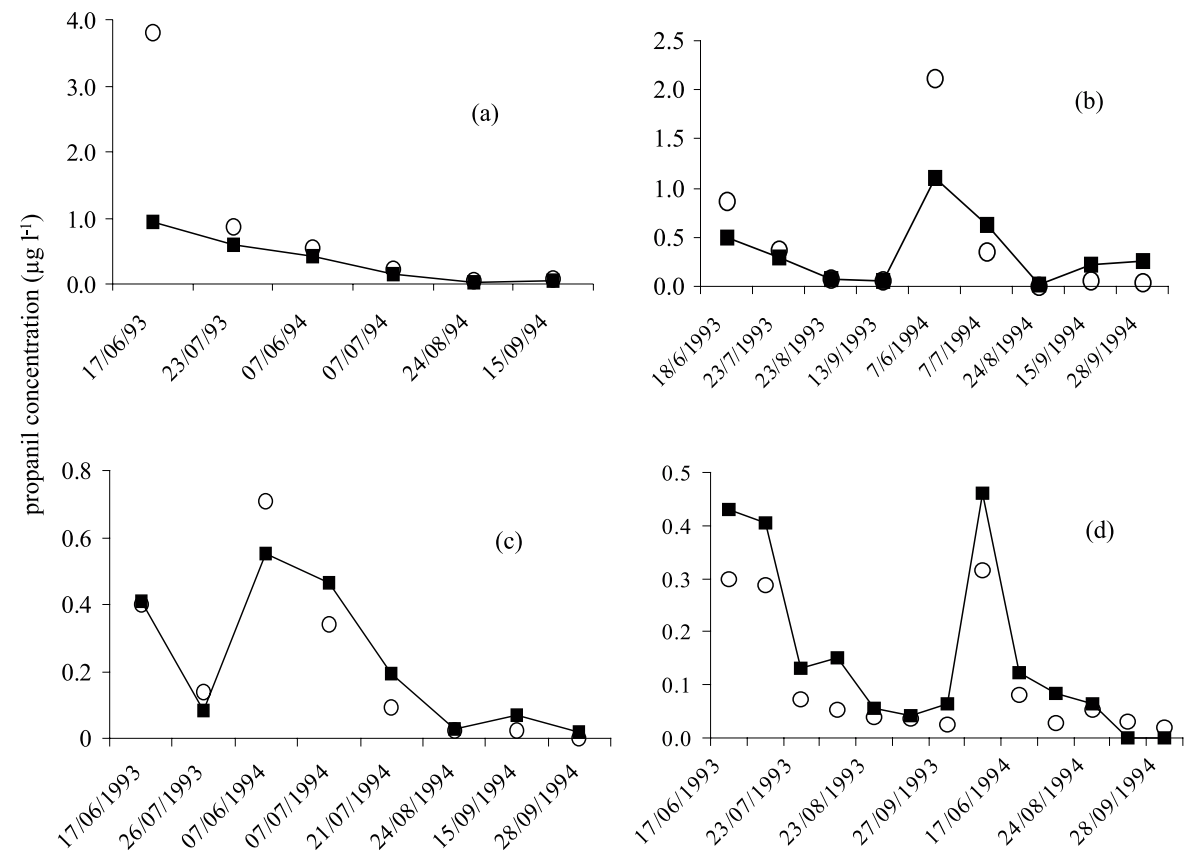

Figure 3. The predicted ( $\mathbf{\square})$ and measured $(\bigcirc)$ concentrations of propanil in the fields Vrahia 1 (a); Vrahia 2 (b); Vrahia 3 (c) and Vrahia 4 (d). 
Table VIII. The predicted pesticide mass balance (\% of the applied pesticide) in the studied paddies.

\begin{tabular}{|c|c|c|c|c|c|c|}
\hline \multirow[t]{2}{*}{ Fields } & \multirow[t]{2}{*}{ Year } & \multicolumn{5}{|c|}{ Processes } \\
\hline & & Seepage & Runoff/Drainage & Decay water & Decay sediment & Decay foliage \\
\hline \multirow[t]{2}{*}{ Vrahia 1} & 1993 & 25.0 & 0.01 & 40.8 & 8.1 & 26.1 \\
\hline & 1994 & 29.9 & 0.00 & 41.4 & 9.8 & 18.9 \\
\hline \multirow[t]{2}{*}{ Vrahia 2} & 1993 & 24.2 & 0.00 & 41.3 & 7.6 & 26.8 \\
\hline & 1994 & 31.4 & 0.00 & 39.9 & 9.9 & 18.9 \\
\hline \multirow[t]{2}{*}{ Vrahia 3} & 1993 & 29.9 & 0.00 & 38.3 & 9.3 & 22.5 \\
\hline & 1994 & 28.3 & 0.00 & 41.9 & 8.8 & 21.0 \\
\hline \multirow[t]{2}{*}{ Vrahia 4} & 1993 & 30.3 & 0.00 & 42.1 & 8.8 & 18.9 \\
\hline & 1994 & 24.4 & 0.01 & 41.7 & 7.1 & 26.8 \\
\hline \multirow[t]{2}{*}{ Halastra } & 1993 & 21.6 & 1.70 & 43.6 & 4.6 & 28.3 \\
\hline & 1994 & 29.3 & 0.00 & 42.7 & 6.2 & 21.7 \\
\hline
\end{tabular}

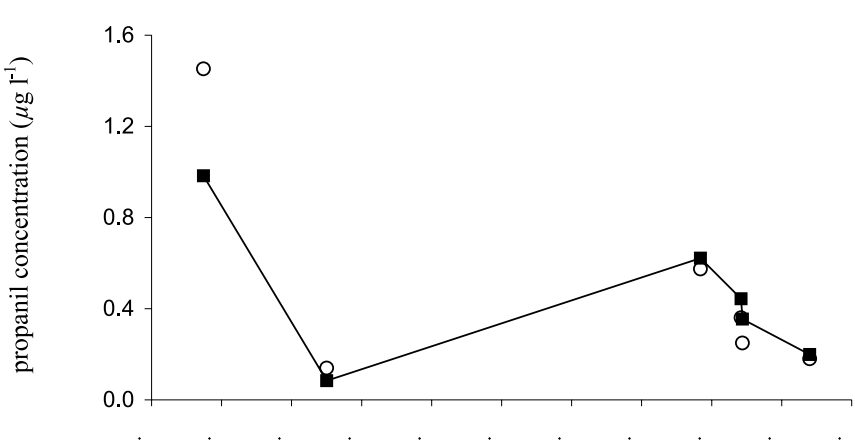

Figure 4. The predicted $(\boldsymbol{\square})$ and measured $(\bigcirc)$ concentrations of propanil in the paddy field of the Halastra area.

along the sides of the suction lysimeters. However, the possibility of incorporating such an artefact in the current field study was minimized by taking special care during lysimeter installation. Bypass flow leaching of solutes could not be adequately described by the VADOFT model [7]. However, this model is the only model currently available for calculating PECs in GWs beneath rice paddies but it should be used with due care when bypass flow mechanisms control pesticide movement in the vadose zone. Further work should focus on the development of a possible interface between RICEWQ and a model which considers macropore flow mechanisms like MACRO [16].

The predicted pesticide mass balance in all studied fields is presented in Table VIII. The model predicted that the most significant routes for propanil dissipation were primarily, pesticide decay in paddy water and secondly, seepage into the vadose zone. Pesticide decay, either in foliage or sediment, was also a major pathway for pesticide dissipation. The predicted minimal losses of propanil by runoff/overflow or controlled drainage could be attributed to the extended closure time of the paddies (5-10 days) following pesticide application. This time period was adequate for propanil concentrations to rapidly decline in paddy water, considering the high decay rate of propanil in water $\left(0.230 \mathrm{~d}^{-1}\right)$. The differences observed among different paddies in the amount of pesticide predicted to degrade in crop foliage could be attributed to the different time of application in the different paddies. Earlier pesticide application coincides with an under-developed crop, a reduced un-submerged crop canopy and subsequently, lower interception of propanil by the crop foliage.

The predicted water balances in the studied paddies are shown in Table IX. Irrigation and seepage into the vadose zone

Table IX. The water balance $\left(\mathrm{m}^{3} \mathrm{ha}^{-1}\right)$ as predicted by the model in the studied paddy fields.

\begin{tabular}{|c|c|c|c|c|c|c|}
\hline \multirow[t]{2}{*}{ Fields } & \multirow[t]{2}{*}{ Year } & \multicolumn{5}{|c|}{ Routes of water inflow and outflow } \\
\hline & & Seepage & Runoff/Drainage & Evapotranspiration & Irrigation & Precipitation \\
\hline \multirow[t]{2}{*}{ Vrahia 1} & 1993 & 12810 & 527.9 & 5299 & 17683.9 & 953 \\
\hline & 1994 & 12981 & 638.3 & 5470 & 17708.3 & 1381 \\
\hline \multirow[t]{2}{*}{ Vrahia 2} & 1993 & 12851 & 249.6 & 5299 & 17446.6 & 953 \\
\hline & 1994 & 13058 & 309.7 & 5470 & 17456.7 & 1381 \\
\hline \multirow[t]{2}{*}{ Vrahia 3} & 1993 & 12796 & 529.6 & 5299 & 17671.6 & 953 \\
\hline & 1994 & 13050 & 694.9 & 5470 & 17845.9 & 1381 \\
\hline \multirow[t]{2}{*}{ Vrahia 4} & 1993 & 12810 & 512.9 & 5299 & 17670.9 & 953 \\
\hline & 1994 & 13039 & 654.0 & 5470 & 17782.0 & 1381 \\
\hline \multirow[t]{2}{*}{ Halastra } & 1993 & 12810 & 571.9 & 5299 & 17727.9 & 953 \\
\hline & 1994 & 13039 & 654.6 & 5470 & 17782.6 & 1381 \\
\hline
\end{tabular}


were the most significant water inflow and outflow processes in the studied paddies. Evapotranspiration was also a significant route for water loss in all paddies, unlike overflow and controlled drainage, which played a minor role in water outflow from the rice paddies. This was expected since the dry and warm climatic conditions usually occurring in the studied area during the rice cropping season contribute to high evapotranspiration losses and minimal overflow due to low precipitation, especially during June and July.

\section{CONCLUSIONS}

A validation test of the model RICEWQ-VADOFT showed that the model predicted, after calibration, with acceptable accuracy the leaching of propanil in specific rice paddies. However, the model failed to predict the leaching behavior of propanil in paddies where preferential flow was probably the dominant mechanism controlling pesticide transport in the vadose zone. RICEWQ-VADOFT could be a useful tool for predicting the environmental fate of pesticides in rice paddies and especially in cases when chromatographic flow and transport of pesticides occurs in the vadose zone. Further work should focus on the development of a novel model interface which would be able to consider preferential flow mechanisms underneath rice paddies.

Acknowledgements: This paper was produced within the framework of a Marie Curie individual fellowship "Environmental risk analysis leading to simulating a sustainable ecosystem management in rice areas" held by Dr. D Karpouzas (QLK5-CT-2002-51598).

\section{REFERENCES}

[1] Accinelli C., Dinelli G., Vicari A., Catizone P., Atrazine and metolachlor degradation in subsoils, Biol. Soil Fertil. 33 (2001) 495-500.

[2] Acutis M., Donatelli M., Soilpar 2.00: Software to estimate soil hydrological parameters and functions, Eur. J. Agron. 18 (2003) 373-377.

[3] Boesten J.J.T.I., van der Linden A.M.A., Modeling the influence of sorption and transformation on pesticide leaching and persistence, J. Environ. Qual. 20 (1991) 425-435.

[4] Brown C.D., Hodkinson R.A., Derek A.R., Syers J.K., Wilcockson S.J., Movement of pesticides to surface waters from a heavy clay soil, Pestic. Sci. 43 (1995) 131-140.

[5] Capri E., Cavanna S., Trevisan M., Ground and surface water bodies contamination by pesticide use in paddy field, in: Capri E., Cervelli $S$. Arnold G. (Eds.), Environmental risk parameters for use of plant protection products in rice, Tipolitographia, Piacenza, 1999, pp. 48-71.

[6] Capri E., Miao Z., Modeling pesticide fate in rice paddy, Agronomie 22 (2002) 363-371.

[7] Carsel R.F., Imhoff J.C., Hummel P.R., Cheplick J.M., Donigian A.S. Jr., PRZM - 3, a model for predicting pesticide and nitrogen fate in the crop root and unsaturated soil zones: Users manual for release 3.0. National Exposure Research Laboratory, Office of Research and Development, U.S. Environmental Protection Agency, Athens, GA, 1998.
[8] Carter A.D., Herbicide movement in soil: principles, pathways and processes, Weed Res. 40 (2000) 113-122.

[9] Clark L., Gomme J., Carter A., WRc/Soil Survey inert suction sampler, Q. J. Eng. Geol. 24 (1992) 241-243.

[10] Donatelli M., Bellocchi G., Fontana F., RadEst 3.00: Software to estimate daily radiation data from commonly available meteorological variables, Eur. J. Agron. 18 (2003) 363-367.

[11] Dubus I.O., Beulke S., Brown C.D., Review: Calibration of pesticide leaching models: critical review and guidance for reporting, Pest Manag. Sci. 58 (2002) 745-758

[12] FOCUS, FOCUS groundwater scenarios in the EU plant protection product review process. Report of the FOCUS Groundwater Scenarios Workgroup, EC Document Reference SANCO 321/2000, Rev. 2, p. 202, 2000

[13] FOCUS, FOCUS surface water scenarios in the EU evaluation process under 91/414/EEC. Report of the FOCUS Working Group on surface water scenarios, EC Document Reference SANCO/ 4802/2001, p. 245, 2001.

[14] FOCUS, Final report of the working group MED-RICE prepared for the European Commission in the framework of Council Directive 91/414/EEC, Document Reference SANCO 1092, p. 106, 2003.

[15] Gomez de Barreda C., Rice scenario, ecology of the paddy field and monitoring studies in Spain, in: Capri E., Cervelli S., Arnold G. (Eds.), Environmental risk parameters for use of plant protection products in rice, Tipolitographia, Piacenza, 1999, pp. 23-28.

[16] Jarvis N.J., The MACRO model (Version 3.1). Technical description and sample simulations. Reports and Dissertation 19. Department of Soil Science, Swedish University of Agricultural Sciences, Uppsala, Sweden, p. 55, 1994.

[17] Linsley P.K., Franjini J.B., Water-resources engineering, 3rd ed., McGraw-Hill, New York, 1979.

[18] Loague K., Green R.E., Statistical and graphical methods for evaluating solute transport models: Overview and application, J. Contam. Hydrol. 7 (1991) 51-73.

[19] Miao Z., Cheplick J.M., Williams W.M., Trevisan M., Padovani L., Gennari M., Ferrero A., Vidotto F., Capri E., Simulating pesticide leaching and runoff in rice paddies with RICEWQ-VADOFT model, J. Environ. Qual. 32 (2003) 2189-2199.

[20] Papadopoulou-Mourkidou E., Karpouzas D.G., Patsias J., Kotopoulou A., Milothridou A., Kintzikoglou K., Vlachou P., The potential of pesticides to contaminate the groundwater resources of the Axios river basin. Part II. Monitoring study in the south part of the basin, Sci. Total Environ. 321 (2004) 147-164.

[21] Pothuluri J.V., Moorman T.B., Obenhuber D.C., Wauchope R.D., Aerobic and anaerobic degradation of alachlor in samples from a surface-to-groundwater profile, J. Environ. Qual. 19 (1990) 525-530.

[22] Santos T.C.R., Rocha J.C., Alonso R.M., Martinez E., Ibanez C., Barcelo D., Rapid degradation of propanil in rice crop fields, Environ. Sci. Technol. 32 (1998) 3479-3484.

[23] Wauchope R.D., Buttler T.M., Hornsby A.G., Augustijn-Beckers P.W.M., Burt J.P., The SCS/ARS/CES pesticide properties database for environmental desicion-making, Rev. Environ. Contam. Toxicol. 123 (1992) 1-164.

[24] Williams W.M., Ritter A.M., Cheplick J.M., Zdinak C.E., RICEWQ: Pesticide runoff model for rice crops - user's manual and program documents version 1.6.1. Waterborne Environmental, S.E Leesburg, VA, 1999.

[25] Yoshida S., Fundamentals of rice crop science. IRRI, Los Banos, Philippines, 1981. 